\title{
Diversity of Endophytic Enterobacteria Associated with Different Host Plants
}

\author{
Adalgisa Ribeiro Torres ${ }^{1}$, Welington Luiz Araújo ${ }^{1,2 *}$, Luciana Cursino ${ }^{1}$, Mariangela Hungria ${ }^{3}$, \\ Fábio Plotegher, Fábio Luís Mostasso ${ }^{3}$, and João Lúcio Azevedo ${ }^{1,2}$ \\ ${ }^{1}$ Genetics Department, "Luiz de Queiroz" College of Agriculture, University of São Paulo (ESALQ/USP), \\ Piracicaba, SP, Av. Pádua Dias, 11, P. O. Box 83, 13400-970, Brazil \\ ${ }^{2}$ Laboratory of Microbial Genetics, NIB, University of Mogi das Cruzes, SP, Brazil \\ ${ }^{3}$ Brazilian Agricultural Research Corporation - Embrapa Soybean, Londrina, PR, Brazil
}

(Received September 18, 2007 / Accepted June 24, 2008)

\begin{abstract}
Fifty-three endophytic enterobacteria isolates from citrus, cocoa, eucalyptus, soybean, and sugar cane were evaluated for susceptibility to the antibiotics ampicillin and kanamycin, and cellulase production. Susceptibility was found on both tested antibiotics. However, in the case of ampicillin susceptibility changed according to the host plant, while all isolates were susceptible to kanamycin. Cellulase production also changed according to host plants. The diversity of these isolates was estimated by employing BOX-PCR genomic fingerprints and 16S rDNA sequencing. In total, twenty-three distinct operational taxonomic units (OTUs) were identified by employing a criterion of $60 \%$ fingerprint similarity as a surrogate for an OTU. The 23 OTUs belong to the Pantoea and Enterobacter genera, while their high diversity could be an indication of paraphyletic classification. Isolates representing nine different OTUs belong to Pantoea agglomerans, $P$. ananatis, $P$. stewartii, Enterobacter sp., and E. homaechei. The results of this study suggest that plant species may select endophytic bacterial genotypes. It has also become apparent that a review of the Pantoea/ Enterobacter genera may be necessary.
\end{abstract}

Keywords: endophytes, BOX-PCR, diversity, cellulase production, antibiotic susceptibility

The study of endophytic microorganisms' genetic diversity is not only important for understanding their ecological role in natural environments, but can also their biotechnological application (Wise et al., 1996). The fate and distribution of a species in a natural environment may in part be ruled by genetic diversity within the species. As such, it is necessary to estimate this diversity. Several high-resolution molecular fingerprinting techniques have been used to assess species and subspecies diversity (Vaneechoutee et al., 1998; Rademaker et al., 2000; Schloter et al., 2000). Ribotyping, repetitive DNA sequences and PCR (Dombek et al., 2000; Carson et al., 2003) techniques have been successfully applied to cluster bacteria from the Enterobacteriaceae, Rhizobiaceae, and Actinobacteridae families (Terasawa et al., 2003; Davelos et al., 2004; Yang et al., 2004). BOX-PCR is a technique based on primers targeting the highly conserved repetitive DNA sequences of the BOXA subunit in bacterial genomes (Rademaker et al., 2000; Lanoot et al., 2004). Moreover, BOX-PCR is based on the observation that outwardly facing oligonucleotide primers, complementary to interspersed repeated sequences, enable the amplification of different-sized DNA fragments, consisting of sequences lying in between these elements. It has been applied in a number of taxonomic studies on plant-associated bacteria (Rademaker et al., 2000; Berg et al., 2002), while only used in two studies on endophytic bacteria (Verma et al., 2001; Krechel et al.,

* To whom correspondence should be addressed.

(Tel) 55-19-3429-4251; (Fax) 55-19-3433-6706

(E-mail)wlaraujo@esalq.usp.br
2002). Interestingly, no studies have analyzed endophytic bacteria from the Enterobacteriaceae family.

The aim of the present study was evaluate the genetic and physiological aspects of endophytic enterobacteria from five commercially important Brazilian host plants (citrus, cocoa, eucalyptus, soybean, and sugar cane) based on production of cellulase (endoglucanase), antibiotic susceptibility and molecular methods, such as BOX-PCR and 16S rRNA gene sequencing.

\section{Materials and Methods}

Bacterial isolates and culture conditions

The bacterial isolates used in this study were obtained from a collection belonging to the Laboratory of Microbial Genetics, Department of Genetics, ESALQ/USP. The isolates were grown in liquid LB media (Sambrook et al., $1989)$ at $28^{\circ} \mathrm{C}$ under agitation (200 rpm).

\section{Susceptibility analysis}

The susceptibility of 53 isolates to antibiotics was determined in the following manner: bacteria were grown in LB broth until $5 \times 10^{5} \mathrm{CFU} / \mathrm{ml}$ according to the guidelines of the National Committee for Clinical Laboratory Standards (NCCLS, 2004). The culture was then spotted with a 16-pin handheld replicator onto the LB agar supplemented with antibiotics. Selective concentrations used were 50 and 100 $\mu \mathrm{g} / \mathrm{ml}$ for ampicillin and kanamycin, respectively. 


\section{Plate cellulase enzyme assays}

Plate assays were performed according to the methods of Teather and Wood (1982). Isolated colonies of 53 bacterial cultures were picked and inoculated using a toothpick on LB agar supplemented with $1.5 \%$ (w/v) carboxy-methyl-cellulose (CMC). The inoculated plates were incubated for $24 \mathrm{~h}$ at $28^{\circ} \mathrm{C}$. After incubation, the plates were flooded with Congo red $(1 \mathrm{mg} / \mathrm{ml})$ solution, incubated at room temperature for $15 \mathrm{~min}$ and washed several times with sterile $1 \mathrm{M}$ $\mathrm{NaCl}$ solution for 10 15 min to remove unbounded excess dye. A clearing zone surrounded by a red background was indicative of $\mathrm{CMC}$ hydrolysis. The cellulase activity index was achieved by the ratio of CMC degradation clear zone diameter and that of bacterial colony.

\section{Genomic DNA extraction}

Genomic DNA was extracted from endophytic bacteria using the following protocol: a $1.5-\mathrm{ml}$ sample of an overnight bacterial culture was centrifuged for $2 \mathrm{~min}$ at $12,000 \times \mathrm{g}$ and re-suspended in $1 \mathrm{ml}$ of TE buffer $(10 \mathrm{mM}$ Tris- $\mathrm{HCl}, 1 \mathrm{mM}$ EDTA, pH 8.0), re-centrifuged, decanted, and re-suspended in $500 \mu \mathrm{l}$ of TE buffer plus $0.5 \mathrm{~g}$ of $0.1-\mathrm{mm}$ diameter glass beads and $30 \mu \mathrm{l}$ of $10 \%$ sodium dodecyl sulfate. The cells were homogenized for $30 \mathrm{sec}$ in a bead beater (Braun cell homogenizer; B. Braun, Germany). A $500 \mu \mathrm{l}$ vol of Tris-buffered phenol was then added, the solution was well mixed and centrifuged for $10 \mathrm{~min}$ at $12,000 \times \mathrm{g}$. The aqueous phase was extracted once with phenol-chloroform (1:1) and once with chloroform, and the DNA was precipitated with isopropanol ( $5 \mathrm{~min}$ at room temperature) and collected by centrifugation $(10 \mathrm{~min}$ at $12,000 \times \mathrm{g})$. The pellet was washed with $70 \%$ ethanol, air dried, and re-suspended in $50 \mu \mathrm{l}$ of TE buffer.

\section{BOX-PCR analysis}

BOX-PCR reactions were performed in a $25-\mu 1$ volume containing 5 10 ng of isolated DNA, $7.5 \mathrm{mM} \mathrm{MgCl}_{2}, 1 \times 10^{6}$ $\mu \mathrm{M}$ of BOX A1R primer; 5'-CTACGGCAAGGCGACGCT GACG-3' (Koeuth et al., 1995), 1 U of the Taq DNA polymerase (Invitrogen, USA), and $0.6 \mathrm{mM}$ each dNTP. DNA amplification was carried out in a thermal cycler (PTC-200, MJ Research, USA) under the following conditions: $95^{\circ} \mathrm{C}$ for $10 \mathrm{~min}$ followed by 30 cycles of $1 \mathrm{~min}$ at $95^{\circ} \mathrm{C}, 1 \mathrm{~min}$ $30 \mathrm{sec}$ at $72^{\circ} \mathrm{C}$. The final extension step was performed at $72^{\circ} \mathrm{C}$ for $10 \mathrm{~min}$. The PCR products were analyzed in $1.5 \%$ agarose gels in Tris-borate-EDTA (TBE) buffer at $100 \mathrm{~V}$. DNA bands were prepared for visualization by staining with ethidium bromide $(0.5 \mu \mathrm{g} / \mathrm{ml})$ for $15 \mathrm{~min}$ and washing in water. Subsequently, they were analyzed under UV light and photographed using the Gel Doc 2000 documentation system (Bio-Rad, USA). A $1 \mathrm{~kb}$ molecular size ladder (Fermentas, Inc., USA) was included in each agarose run.

\section{Computer-assisted analysis of BOX-PCR DNA finger- prints}

PCR reactions were electrophoresed on $1.5 \%$ agarose gel for $2 \mathrm{~h}$ at $100 \mathrm{~V}$. Gels were stained with ethidium bromide (15 min). Images were captured and saved directly as TIFF files and processed by BioNumerics 3.0 (Applied Maths, Belgium). Similarity matrices of densitometric curves were calculated by a Jaccard correlation coefficient. Cluster analyses of similarity matrices were performed by an unweighted pair group method with an arithmetic mean (UPGMA) algorithm. The correlation was expressed as percent similarity. Minimum similarity at a level of $60 \%$ between isolates was randomly used as the criterion to define an operational taxonomic unit (OTU) (Yang et al., 2004).

Bacterial identification by $16 \mathrm{~S}$ rRNA gene sequencing The molecular identification of isolates representative of some OTUs was done based on 16S rRNA gene sequencing. For this, the $16 \mathrm{~S}$ rDNA was amplified using the primers 27F; 5'-AGAGTTTGATCMTGGCTCAG-3' and 1378R; 5'-CGG TGTGTACAAGGCCCGGGAACG-3' under the following PCR conditions: $4 \mathrm{~min}$ at $94^{\circ} \mathrm{C}, 30 \mathrm{cycles}$ of $30 \mathrm{sec}$ at $94^{\circ} \mathrm{C}$, $1 \mathrm{~min}$ at $62.5^{\circ} \mathrm{C}$, and $1 \mathrm{~min}$ at $72^{\circ} \mathrm{C}$, followed by a final extension step of $1 \mathrm{~min}$ at $72^{\circ} \mathrm{C}$. The PCR master mix contained $3.75 \mathrm{mM} \mathrm{MgCl}, 0.2 \mathrm{mM}$ dNTP, $0.2 \mu \mathrm{M}$ primer, $2.5 \mathrm{U}$ Taq DNA polymerase, $1 \times$ PCR buffer and $1 \mu \mathrm{l}$ DNA template $(0.5 \sim 10 \mathrm{ng})$. The PCR products were purified using a GFX PCR DNA and gel band purification kit (Amersham Biosciences) and sequenced using the 1378R primer. Analyses of sequences were performed with the basic sequence alignment program, BLAST, which ran against the database [National Center for Biotechnology Information website (http://www.ncbi.nlm.nih.gov/BLAST)]. The determined sequence were aligned using CLUSTAL $\mathrm{W}$ and the distance matrices and phylogenetic trees were calculated by Jukes and Cantor (1969) and neighbour-joining (Saitou and Nei, 1987) algorithms, respectively, using MEGA4.0 software. The nucleotide sequences obtained in this study have been submitted to the GenBank and assigned accession numbers AY914088, AY914093, AY914097, AY914789, AY914792, AY914795, AY920254, AY920255, AY920524.

\section{Diversity index estimation}

The Shannon diversity index $\left(\mathrm{H}=-\sum\left(\mathrm{x}_{\mathrm{i}} / \mathrm{x}_{0}\right) \ln \left(\mathrm{x}_{\mathrm{i}} / \mathrm{x}_{0}\right)\right.$ where $\mathrm{x}_{\mathrm{i}}=$ number of isolates in an OTU and $\mathrm{x}_{0}=$ total number of isolates) was calculated for each host plant in the BOX-PCR experiments (Margurran, 1988).

\section{Statistical analysis}

Data analysis was performed using the SAS software package version 6.0 (SAS, 1987). For BOX-PCR experiments, a

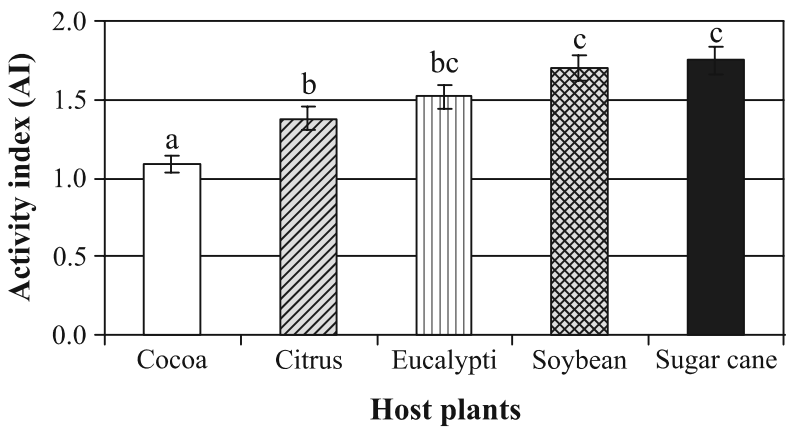

Fig. 1. Cellulase activity index (AI) of bacterial isolates from five host plants. AI for each host plant was averaged. 
Table 1. Bacterial isolates used, with their relevant characteristics

\begin{tabular}{|c|c|c|c|c|c|c|}
\hline Isolates & Species & Host plant & OTUs & $\begin{array}{l}\text { Ampicillin } \\
\text { phenotype }\end{array}$ & $\begin{array}{l}\text { Cellulase } \\
\text { production }\end{array}$ & Reference or source ${ }^{a}$ \\
\hline ARB18 & Pantoea agglomerans & Citrus & 10 & $\mathrm{~S}$ & + & Araújo et al. (2002) \\
\hline ARB18/10 & & Citrus & 10 & $\mathrm{R}$ & + & Araújo et al. (2002) \\
\hline CL12 & & Citrus & 9 & $\mathrm{R}$ & - & Araújo et al. (2001) \\
\hline CTO2 & & Citrus & 9 & $\mathrm{R}$ & - & Araújo et al. (2001) \\
\hline CTO5 & & Citrus & 9 & $\mathrm{R}$ & - & Araújo et al. (2001) \\
\hline LC32 & & Citrus & 9 & $\mathrm{R}$ & - & Araújo et al. (2001) \\
\hline LCO6 & & Citrus & 9 & $\mathrm{R}$ & - & Araújo et al. (2001) \\
\hline LT37 & & Citrus & 9 & $\mathrm{R}$ & - & Araújo et al. (2001) \\
\hline LV23 & & Citrus & 9 & $\mathrm{R}$ & - & Araújo et al. (2001) \\
\hline LV24 & & Citrus & 9 & $\mathrm{R}$ & - & Araújo et al. (2001) \\
\hline PR1.5/2 & & Citrus & 5 & S & + & Araújo et al. (2002) \\
\hline PR1.5/4 & & Citrus & 5 & $\mathrm{R}$ & + & Araújo et al. (2002) \\
\hline PR1.5/9 & & Citrus & 3 & $\mathrm{R}$ & - & Araújo et al. (2002) \\
\hline PR1/4 & & Citrus & 15 & $\mathrm{R}$ & - & Araújo et al. (2002) \\
\hline $\mathrm{PR} 2 / 7$ & Enterobacter cloacae & Citrus & 12 & S & - & Araújo et al. (2002) \\
\hline TC41 & & Citrus & 9 & $\mathrm{R}$ & - & Araújo et al. (2001) \\
\hline TO45 & & Citrus & 9 & $\mathrm{R}$ & - & Araújo et al. (2001) \\
\hline TO47 & & Citrus & 9 & $\mathrm{R}$ & - & Araújo et al. (2001) \\
\hline TS49 & & Citrus & 9 & $\mathrm{R}$ & - & Araújo et al. (2001) \\
\hline TS51 & & Citrus & 9 & $\mathrm{R}$ & - & Araújo et al. (2001) \\
\hline $\mathrm{C} 32.2$ & & Cocoa & 12 & $\mathrm{R}$ & - & ESALQ/USP $^{\mathrm{b}}$ \\
\hline C33.2 & & Cocoa & 12 & $\mathrm{R}$ & + & ESALQ/USP \\
\hline C35.1 & & Cocoa & 12 & $\mathrm{R}$ & - & ESALQ/USP \\
\hline C39.1 & & Cocoa & 1 & $\mathrm{R}$ & - & ESALQ/USP \\
\hline C40.1 & & Cocoa & 1 & $\mathrm{R}$ & - & ESALQ/USP \\
\hline C41.1 & & Cocoa & 12 & $\mathrm{R}$ & + & ESALQ/USP \\
\hline C45.1 & & Cocoa & 12 & $\mathrm{R}$ & - & ESALQ/USP \\
\hline C49.1 & & Cocoa & 12 & $\mathrm{R}$ & - & ESALQ/USP \\
\hline C55.1 & & Cocoa & 1 & $\mathrm{R}$ & - & ESALQ/USP \\
\hline C56.1 & & Cocoa & 1 & $\mathrm{R}$ & - & ESALQ/USP \\
\hline ECE5 & & Eucalyptus & 8 & $\mathrm{R}$ & - & Procópio (2004) \\
\hline ECE6 & & Eucalyptus & 4 & $\mathrm{R}$ & + & Procópio (2004) \\
\hline ECE7 & & Eucalyptus & 6 & $\mathrm{R}$ & + & Procópio (2004) \\
\hline EGE1 & Pantoea agglomerans & Eucalyptus & 10 & S & + & Procópio (2004) \\
\hline EGE6 & & Eucalyptus & 13 & S & + & Procópio (2004) \\
\hline EGE8 & & Eucalyptus & 10 & S & + & Procópio (2004) \\
\hline EGS2 & & Eucalyptus & 17 & S & + & Procópio (2004) \\
\hline EIE3 & & Eucalyptus & 14 & S & + & Procópio (2004) \\
\hline EIE6 & & Eucalyptus & 22 & S & + & Procópio (2004) \\
\hline ETE7 & Hafnia alvei & Eucalyptus & 6 & $\mathrm{R}$ & - & Procópio (2004) \\
\hline ETE8 & & Eucalyptus & 4 & $\mathrm{R}$ & + & Procópio (2004) \\
\hline EUE6 & & Eucalyptus & 18 & S & + & Procópio (2004) \\
\hline EUE7 & Pantoea ananatis & Eucalyptus & 7 & $\mathrm{R}$ & + & Procópio (2004) \\
\hline EN80 & & Soybean & 2 & S & + & Kuklinsky-Sobral et al. (2004) \\
\hline EN103 & & Soybean & 21 & $\mathrm{R}$ & + & Kuklinsky-Sobral et al. (2004) \\
\hline EN179 & & Soybean & 16 & S & + & Kuklinsky-Sobral et al. (2004) \\
\hline EN192 & & Soybean & 23 & S & + & Kuklinsky-Sobral et al. (2004) \\
\hline EN306 & & Soybean & 11 & S & + & Kuklinsky-Sobral et al. (2004) \\
\hline ENB73 & & Soybean & 8 & $\mathrm{R}$ & - & Kuklinsky-Sobral et al. (2004) \\
\hline 2B9 & & Sugar cane & 6 & $\mathrm{R}$ & + & ESALQ/USP \\
\hline 64 R1 & & Sugar cane & 20 & S & + & ESALQ/USP \\
\hline $65 \mathrm{R} 1$ & & Sugar cane & 19 & S & + & ESALQ/USP \\
\hline $66 \mathrm{R} 1$ & & Sugar cane & 19 & S & + & ESALQ/USP \\
\hline
\end{tabular}


series of T-tests were performed according to the methods proposed by Magurran (1988) in order to detect statistical difference in diversity indices.

\section{Results}

\section{Cellulase production and antibiotic susceptibility}

We characterized 53 enterobacteria endophytes for the production of cellulase and antibiotic susceptibility. The lowest cellulase production was found for cocoa plants in which 2 out of $10(20 \%)$ isolates were able to produce this enzyme in vitro. A similar production percentage was observed for citrus in which 4 out of $20(20 \%)$ isolates produced cellulase. The highest average of cellulase production was observed for soybean (5 out of 6 ), eucalyptus (11 out of 13$)$, and sugarcane (4 out of 4), showing 83, 84.6, and $100 \%$, respectively. Similarly, the cellulase activity index (AI) was lower for cocoa followed by citrus. Eucalyptus, soybean, and sugar cane, on

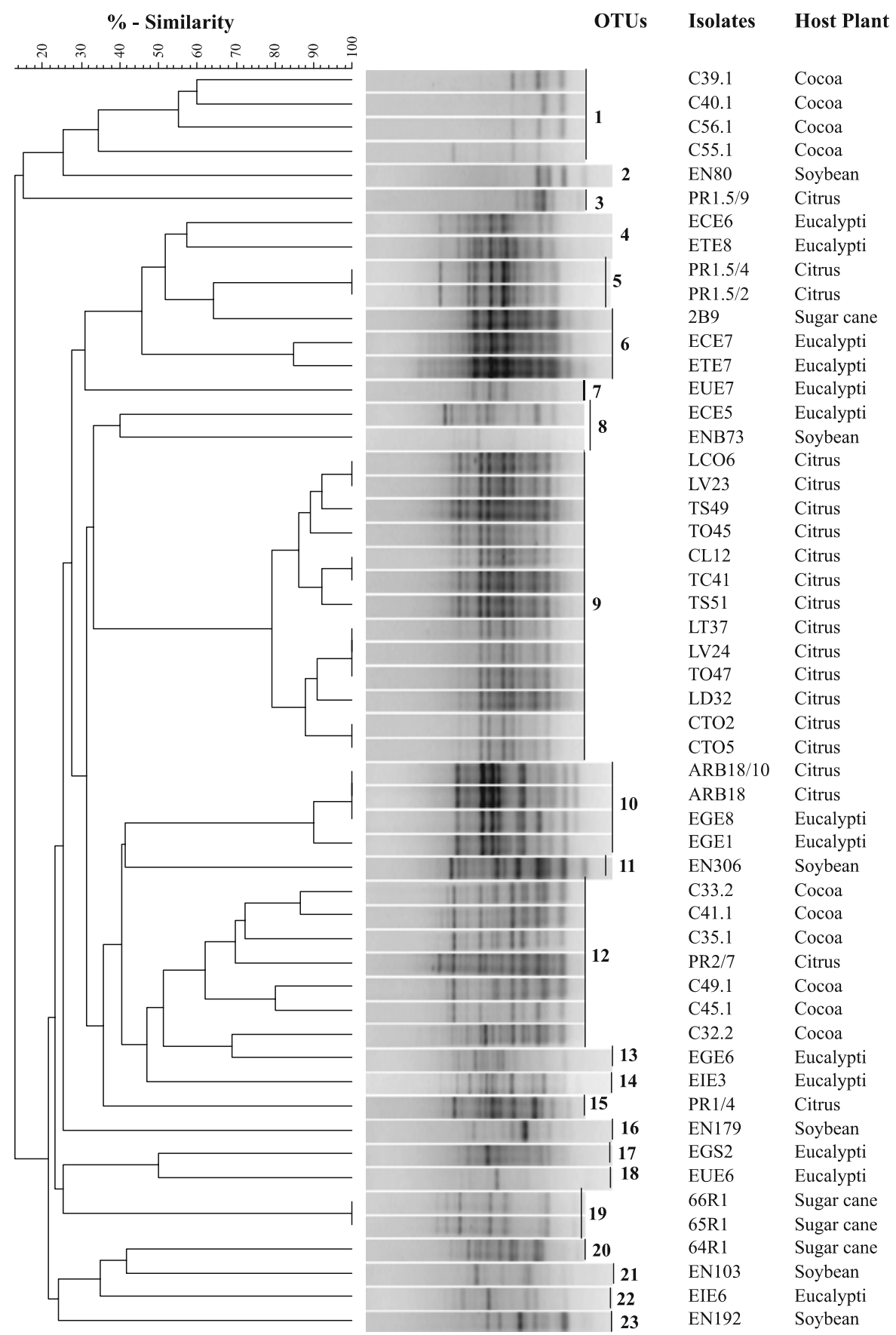

Fig. 2. Dendrogram by UPGMA clustering of BOX-PCR fingerprints of 53 bacterial isolates from citrus, cocoa, eucalyptus, soybean, and sugar cane. Clustering using Jaccard product-moment coefficient was expressed as percentage similarity. 


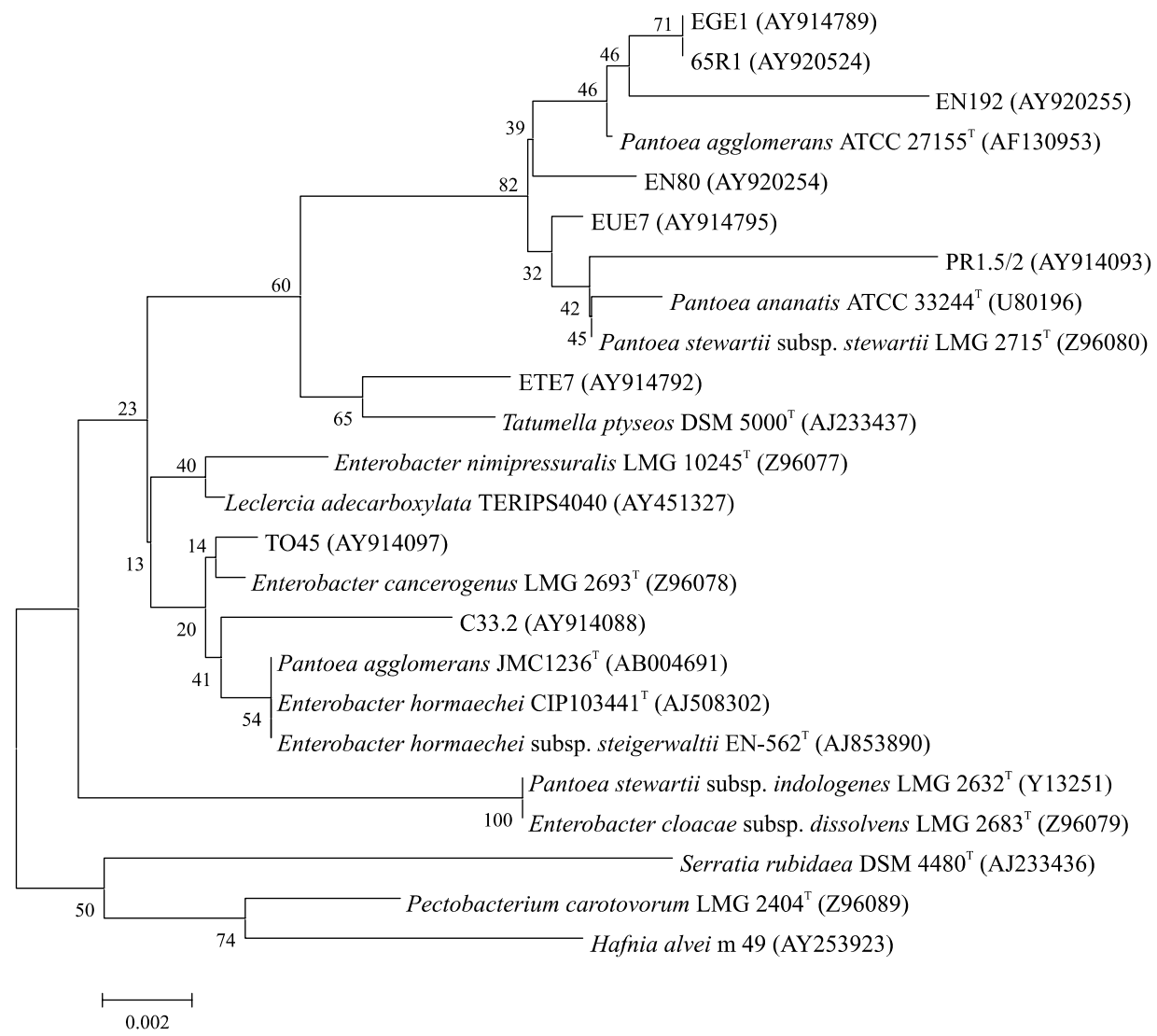

Fig. 3. Phylogenetic relationships of Enterobacteriaceae based on partial $16 \mathrm{~S}$ rDNA sequences obtained from the endophytic bacteria and closely related sequences, based on a distance analysis (neighbour-joining algorithm with Jukes-Cantor model; 1,000 bootstrap replicates performed).

the other hand, presented higher AI values (Fig. 1). For antibiotic susceptibility, all tested isolates were susceptible to kanamycin. Regarding ampicillin, susceptibility was heterogeneous according to the host plant (Table 1). The susceptibility to this antibiotic was observed as follows: citrus $(15 \%)$, eucalyptus $(54 \%)$, soybean $(67 \%)$, and sugar cane (75\%) (data not shown). Cocoa isolates did not exhibit susceptibility to ampicillin (Table 1).

\section{BOX-PCR DNA fingerprint of endophytic entero- bacteria}

BOX-PCR was performed on 53 endophytic bacteria belonging to the Enterobacteriaceae family isolated from cocoa, citrus, eucalypti, soybean, and sugar cane host plants. Curvebased product-moment correlation coefficients were used for pairwise fingerprint comparison, and UPGMA was used to perform cluster analysis on all isolates (Fig. 2). Through cluster analysis of the BOX-PCR profiles at $55 \%$ as arbitrary similarity level, 23 different OTUs (comprising 9 clusters and 14 unique profiles) were identified. We observed that $52.7 \%$ of the isolates were included in only 4 OTUs, with OTU9 and OTU12 being most frequent with 24.5 and $13.2 \%$ of the isolates.

Representative isolates from the most frequent OTUs were identified by $16 \mathrm{~S}$ rRNA gene sequencing, which showed that the population evaluated is composed of at least 6 spe- cies, including Pantoea agglomerans, $P$. ananatis, $P$. stewartii, Enterobacter cancerogenus, E. hormaechei, and Tatumella ptyseos (Fig. 3). OTU9 comprised of 13 isolates obtained from citrus plants and identified according to biochemical profile as $P$. agglomerans (Araújo et al., 2002). However, $16 \mathrm{~S}$ rRNA gene sequencing of the isolate TO45 showed that it is close to Enterobacter cancerogenus LMG2693 ${ }^{\mathrm{T}}$ (Fig. 3). OTU12 included 6 cocoa and 1 citrus isolates, and the isolate $\mathrm{C} 33.2$, which seems to be a divergent genotype in Enterobacter genera (Fig. 3). In OTU2, OTU10, OTU19, and OTU23, the isolates EN80, EGE1, 65R1, and EN192, respectively, showed similarity with $P$. agglomerans ATCC $27155^{\mathrm{T}}$, while the isolates included in OTU5 and OTU7 are closed related to $P$. ananatis ATCC $33244^{\mathrm{T}}$ and $P$. stewartii subsp. stewartii LMG $2715^{\mathrm{T}}$ (Fig. 3).

OTU6 had three isolates (one from sugar cane and two from eucalyptus), and since the sequence of isolate ETE7 matched (98\%) with unidentified Enterobacteriaceae (EU 029106), this group was assumed to be a divergent genotype. However, the phylogenetic tree suggests that this group is related to Tatumella genera (Fig. 3).

Interaction among cellulase, antibiotic phenotypes, and BOX-PCR DNA fingerprint

We analyzed the interaction between phenotypes (cellulase and ampicillin resistance) and genotypes (BOX-PCR DNA 
fingerprint) of the evaluated bacteria. Isolates from OTUs 9 and 1 (citrus and cocoa plants, respectively) were resistant to ampicillin and negative for cellulase production (Table 1). However, this result was not observed for OTUs 10 and 12, which showed variable phenotypes. In contrast, except for isolate PR2/7 (OTU 12), ampicillin susceptive isolates showed cellulase production (16 out of 17 isolates).

\section{Discussion}

Understanding microbial biodiversity in association with recombinant DNA technique may provide the basis for utilization of endophytes in agriculture. Detailed molecular diversity information may help us to understand the evolution of microbial functionality in their particular environment, creating new genetic variants below the species level. The selection of newly acquired functions may help us to understand the functional diversity of microbial communities and ultimately ecosystem function as a whole (Schloter et al., 2000).

Our research goals were to characterize endophytic enterobacteria isolates from five commercially important crops for susceptibility to antibiotics and cellulase (endoglucanase) production. We also evaluated the genetic diversity of these isolates using the powerful BOX-PCR technique followed by $16 \mathrm{~S}$ rRNA gene sequencing.

Initially, we analyzed all the isolates for antibiotic susceptibility and cellulase production. We found susceptibility to both tested antibiotics, which in ampicillin changed according to the host plant. Cellulase production also changed according to the host plant. As such, cellulase production is a characteristic possibly required for endophytic colonization (Germaine et al., 2004), since endophytic colonization is an active process and not simply the passive diffusion of bacteria into the intercellular spaces of plants (Dong et al., 2003). Furthermore, cell wall degradation by endophytes may trigger systemic resistance induction (Hallmann et al., 1997).

According to Germaine et al. (2004), endophytic bacteria may lose antibiotic resistance after its introduction in plants. This finding is corroborated by our results, since we observed that in ampicillin sensible population, $94.1 \%$ were able to produce cellulase, while in antibiotic resistant population this decreased to $27.8 \%$. Therefore, we suggest that the ability to establish inside the host plant, by cell wall degradation, may be related to the loss of some phenotypes, such as antibiotic resistance.

After this, BOX-PCR was selected as the molecular typing technique for the enterobacteria endophytic isolates. This is because BOX-PCR is reproducible, rapid, easy to perform, and highly discriminatory at the subspecies level (Olive and Bean, 1999), yielding results that correlate well with pairwise DNA-DNA analyses (Rademaker et al., 2000). The BOX-PCR genomic fingerprint patterns were analyzed by a curve-based protocol, which retains more information than merely the number and position of fingerprint fragments (Hane et al., 1993; Yang et al., 2004). In the present study, 23 OTUs were observed in 53 isolates analyzed by BOXPCR fingerprint. OTU9 and OTU1 were observed only in citrus and cocoa bacterial population, respectively.
The isolates belonging to these OTUs didn't produced cellulase and were ampicillin resistant. Also, all cocoa isolates belonged to OTU1 and OTU12, and showed ampicillin resistance. These results suggest that correlation between host genotype, and genetic and phenotypic characteristic of the bacteria, could drive the endophytic-plant interaction.

In our work, the genetic diversity of 53 isolates analyzed by BOX-PCR fingerprint grouped in 23 different OTUs mostly showed a non-strictly OTU-host relationship. This had implications in the diversity indices of these hosts, which was higher for eucalyptus and soybean isolates. According to Yang et al. (2004), the presence of 23 OTUs could indicate that the 53 isolates are comprised of up to 23 different species, since when microbial diversity is inferred from BOX-PCR, individual OTUs must be defined as species surrogates. However, no consistent definition of OTUs is currently employed, leading to a non-comparable estimate. Here, isolates representing nine different OTUs was identified by $16 \mathrm{~S}$ rRNA gene sequencing, belonged to $P$. agglomerans, $P$. ananatis, $P$. stewartii, Enterobacter cancerogenus, E. hormaechei, and Tatumella ptyseos. This suggests that the OTUs observed in our work could be species closely related to the Pantoea genus or subspecies of $P$. agglomerans and $P$. ananatis. This hypothesis is supported by Yang et al. (2004) who state that BOX-PCR is a higher genomic resolution technique for diversity estimation within species, which means that it is powerful for subspecies diversity examination.

In this study, we observed high variability in endophytic Enterobacteriaceae, including OTUs that share less than $20 \%$ of the BOX-PCR bands. Furthermore, the P. agglomerans strains were not in the same group, being the type strain JCM1236 closely related to E. hormaechei. These results suggest that some species, such as $P$. agglomerans and $P$. stewartii, could be polyphyletic.

In summary, the BOX-PCR technology was highly successful in discriminating closely related bacteria from the Enterobacteriaceae family. Finally, it is hoped that this line of research will be continued and expanded in order to provide further interesting insights into the understanding of the endophytic enterobacteria community from other commercially important crops.

\section{Acknowledgements}

Funding for this research was provided by the FAPESP project no. 02/14143-3. We thank M.C. Quecine (ESALQ/USP) for assistance and production of statistical analysis. We also gratefully acknowledge CAPES and CNPQ for providing the scholarship to A.R. Torres and L. Cursino, and FAPESP for providing the fellowship to W.L. Araújo.

\section{References}

Araújo, W.L., W. Maccheroni, C.I. Aguilar-Vildoso, P.A.V. Barroso, H.O. Saridakis, and J.L. Azevedo. 2001. Variability and interactions between endophytic bacteria and fungi isolated from leaf tissues of citrus rootstocks. Can. J. Microbiol. 47, 229-236. Araújo, W.L., J. Marcon, W. Maccheroni, J.D. Van Elsas, J.W.L. Van Vuurde, and J.L. Azevedo. 2002. Diversity of endophytic bacterial populations and their interaction with Xylella fastidiosa in citrus plants. Appl. Environ. Microbiol. 68, 4906-4914. 
Berg, G., B. Roskot, A. Steidle, L. Eberl, A. Zock, and K. Smalla. 2002. Plant-dependent genotypic and phenotypic diversity of antagonistic rhizobacteria isolated from different Verticillium host plants. Appl. Environ. Microbiol. 68, 3328-3338.

Carson, C.A., B.L. Shear, M.R. Ellersieck, and J.D. Schnell. 2003. Comparison of ribotyping and repetitive extragenic palindromic-PCR for identification of fecal Escherichia coli from humans and animals. Appl. Environ. Microbiol. 69, 1836-1839.

Davelos, A.L., L.L. Kinkel, and D.A. Samac. 2004. Spatial variation in the frequency and intensity of antibiotic interactions among Streptomycetes from prairie soil. Appl. Environ. Microbiol. 70, 1051-1058.

Dombek, P.E., L.K. Johnson, S.T. Zimmerley, and M.J. Sadowsky. 2000. Use of repetitive DNA sequences and the PCR to differentiate Escherichia coli isolates from human and animal sources. Appl. Environ. Microbiol. 66, 2572-2577.

Dong, Y., A.L. Iniguez, and E.W. Triplett. 2003. Quantitative assessments of the host range and strain specificity of endophytic colonization by Klebsiella pneumoniae 342. Plant Soil 257, 49-59.

Germaine, K., E. Keogh, G. Garcia-Cabellos, B. Borremans, D. Van Der Lelie, T. Barac, L. Oeyen, J. Vangronsveld, F.P. Moore, E.R.B. Moore, C.D. Campbell, D. Ryan, and D.N. Dowling. 2004. Colonisation of poplar trees by $g f p$ expressing bacterial endophytes. FEMS Microbiol. Ecol. 48, 109-118.

Hallmann, J., A. Quadt-Hallmann, W.F. Mahaffee, and J.W. Kloepper. 1997. Bacterial endophytes in agricultural crops. Can. J. Microbiol. 43, 895-914.

Hane, B.G., K. Jager, and H.G. Drexler. 1993. The Pearson product moment correlation coefficient is better suited for identification of DNA fingerprints profiles than band matching algorithms. Electrophoresis 14, 967-972.

Jukes, T.H. and C.R. Cantor. 1969. Evolution of protein molecules, p. 21-132. In H.N. Munro (ed.), Mammalian protein metabolism. Academic Press, New York, N.Y., USA.

Koeuth, T., J. Versalovic, and J.R. Lupski. 1995. Differential subsequence conservation of interspersed repetitive Streptococcus pneumoniae BOX elements in diverse bacteria. Genome Res. $5,408$.

Krechel, A., A. Faupel, J. Hallmann, A. Ulrich, and G. Berg. 2002. Potato-associated bacteria and their antagonistic potential towards plant-pathogenic fungi and the plant-parasitic nematode Meloidogyne incognita (Kofoid \& White) Chitwood. Can. J. Microbiol. 48, 772-785.

Kuklinsky-Sobral, J., W.L. Araújo, R. Mendes, I.O. Geraldi, A.P. Pizzirani-Kleiner, and J.L. Azevedo. 2004. Isolation and characterization of soybean-associated bacteria and their potential for plant growth promotion. Environ. Microbiol. 6, 1244-1251.

Lanoot, B., M. Vancanneyt, P. Dawyndt, M. Cnockaert, J. Zhang, Y. Huang, Z. Liu, and J. Swings. 2004. BOX-PCR fingerprinting as a powerful tool to reveal synonymous names in the genus streptomyces. Emended descriptions are proposed for the species Streptomyces cinereorectus, S. fradiae, S. tricolor, S. colombiensis, S. filamentosus, S. vinaceus, and S. phaeopurpureus. Syst. Appl. Microbiol. 27, 84-92.

Margurran, A.E. 1998. Ecological diversity and its measurements. Princeton University Press, Princeton, New Jersey, USA.

NCCLS - National Committee for Clinical Laboratory Standards. Performance Standards for Antimicrobial Susceptibility Testing. $15^{\text {th }}$ ed. NCCLS document M. 100 - S15: National Committee for Clinical Laboratory Standards, 2004 Villanova, PA, USA.

Olive, D.M. and P. Bean. 1999. Principles and applications of methods for DNA-based typing of microbial organisms. $J$. Clin. Microbiol. 37, 1661-1669.

Procópio, R.E.L. 2004. Diversidade bacteriana endofítica de Eucalyptus spp. e avaliação do seu potencial biotecnológico. Ph. D. thesis. Universidade de São Paulo, São Paulo, Brazil.

Rademaker, J.L.W., B. Hoste, F.J. Louws, K. Kerters, J. Swings, L. Vauterin, P. Vauterin, and F.J. De Brujin. 2000. Comparison of AFLP and rep-PCR genomic fingerprints with DNA-DNA homology studies: Xanthomonas as a model system. Int. J. Syst. Evol. Microbiol. 50, 665-677.

Saitou, N. and M. Nei. 1987. The neighbor-joining method: a new method for reconstructing phylogenetic trees. Mol. Biol. Evol. 4, 406-425.

SAS Institute, Inc. 1987. SAS/STAT guide for personal computers, version 6. SAS Institute, Inc., Cary, N.C., USA.

Schloter, M., M. Lebuhn, T. Heulin, and A. Hartmann. 2000. Ecology and evolution of bacterial microdiversity. FEMS Microbiol. Rev. 24, 647-660.

Teather, R.M. and P.J. Wood. 1982. Use of Congo red-polysaccharide interactions in enumeration and characterization of cellulolytic bacteria from bovine rumen. Appl. Environ. Microbiol. 43, 777-780

Terasawa, G.L.V., B.C. Glienke, and M. Hungria. 2003. Diversity of a soybean rhizobial population adapted to a cerrados soil. World J. Microbiol. Biotechnol. 19, 933-939.

Vaneechoutte, M., P. Boerlin, H.V. Tichy, E. Bannerman, B. Jager, and J. Bille. 1998. Comparison of PCR-based DNA fingerprinting techniques for the identification of Listeria species and their use for atypical Listeria isolates. Int. J. Syst. Bacteriol. 48, 127-139.

Verma, S.C., J.K. Ladha, and A.K. Tripathi. 2001. Evaluation of plant growth promoting and colonization ability of endophytic diazotrophs from deep water rice. J. Biotechnol. 91, 127-141.

Wise, M.G., J. Vaun McArthur, C. Wheat, and L.J. Shimkets. 1996. Temporal variation in genetic diversity and structure of a lotic population of Burkholderia (Pseudomonas) cepacia. Appl. Environ. Microbiol. 62, 1558-1562.

Yang, H.H., R.T. Vinopal, D. Grasso, and B.F. Smets. 2004. High diversity among environmental Escherichia coli isolates from a bovine feedlot. Appl. Environ. Microbiol. 70, 1528-1536. 